\title{
IDENTIFIKASI BAKTERI AEROB PADA MAKANAN JAJANAN JAGUNG BAKAR DI PINGGIRAN JALAN RING ROAD MANADO
}

\author{
${ }^{1}$ Andreano Ch. Porotu'o \\ ${ }^{2}$ Velma Buntuan \\ ${ }^{3}$ Fredine Rares
}

\author{
${ }^{1}$ Kandidat Skripsi Fakultas Kedokteran Universitas Sam Ratulangi \\ ${ }^{2,3}$ Bagian Mikrobiologi Fakultas Kedokteran Universitas Sam Ratulangi \\ E-maill: andre_11_185@yahoo.com
}

\begin{abstract}
Corn is a food that is usually made in the form of roasted corn. Microbial contamination in food can through environmental pollution, behavior management of food, equipment processing, processing space and seasonings. Contaminated food can cause food poisoning. The purpose of this research is to determine the aerobic bacteria in roasted corn street food on the outskirts of the Ring Road Street Manado. This research used a prospective descriptive method. Samples taken are roasted corn, with a total sample of 20 samples and sampling method using random sampling method, then performed the isolation and identification of bacteria. The results of the research from 10 samples of roasted corn not smeared seasonings showed 1 sample no growth and 9 samples growth, i.e. Bacillus subtilis, Enterobacter agglomerans, Serratia rubidaea, Lactobacillus sp., Gram-negative coccus, and Enterobacter cloacae, then 10 samples of roasted corn smeared seasonings showed 1 sample no growth and 9 samples growth, i.e. Bacillus subtilis, Enterobacter agglomerans, Serratia rubidaea, Lactobacillus sp., Enterobacter cloacae, Streptococcus sp., and Pseudomonas sp. The conclusion of this research is the discovery of bacteria in roasted corn not smeared and smeared seasonings. This indicates that the processing is not hygienic.
\end{abstract}

Keywords: Roasted Corn, Seasonings, Aerobic Bacteria

\begin{abstract}
Abstrak: Jagung merupakan bahan makanan yang biasanya dibuat dalam bentuk jagung bakar. Pencemaran mikroba pada makanan dapat melalui polusi lingkungan, perilaku pengelolaan makanan, alat-alat pengolahan, ruang pengolahan dan bumbu penyedap. Makanan yang terkontaminasi dapat menyebabkan keracunan makanan. Tujuan dari penelitian ini yaitu untuk mengetahui bakteri aerob pada makanan jajanan jagung bakar di pinggiran jalan Ring Road Manado. Penelitian ini menggunakan metode deskriptif prospektif. Sampel yang diambil adalah jagung bakar, dengan jumlah sampel sebanyak 20 sampel dan cara pengambilan sampel menggunakan random sampling method, kemudian dilakukan isolasi dan identifikasi bakteri. Hasil penelitian dari 10 sampel jagung bakar tidak dioleskan bumbu penyedap menunjukkan 1 sampel tidak ada pertumbuhan dan 9 sampel ada pertumbuhan, yaitu terdiri dari Bacillus subtilis, Enterobacter agglomerans, Serratia rubidaea, Lactobacillus sp., Kokus gram negatif, dan Enterobacter cloacae, kemudian 10 sampel jagung bakar dioleskan bumbu penyedap menunjukkan 1 sampel tidak terdapat pertumbuhan dan 9 sampel terdapat pertumbuhan, yaitu terdiri dari Bacillus subtilis, Enterobacter agglomerans, Serratia rubidaea, Lactobacillus sp., Enterobacter cloacae, Streptococcus sp., dan Pseudomonas sp. Kesimpulan pada penelitian ini yaitu ditemukannya bakteri pada jagung bakar tidak dioleskan dan dioleskan bumbu penyedap. Hal ini menandakan bahwa pengolahannya tidak higienis.
\end{abstract}

Kata kunci: Jagung Bakar, Bumbu Penyedap, Bakteri Aerob 
Jagung merupakan bahan makanan pokok utama pengganti beras. ${ }^{1,2}$ Jagung merupakan salah satu komoditas pangan yang kaya karbohidrat dan dinilai sangat layak untuk dijadikan sumber makanan yang dapat diolah menjadi produk siap saji bagi sebagian besar masyarakat Indonesia seperti di Sulawesi, Jawa Timur dan Jawa Tengah. ${ }^{1-3}$

Jagung biasanya dibuat dalam bentuk makanan tradisional seperti jagung bakar, nasi jagung, bubur jagung dan jagung campuran beras. ${ }^{1,4}$ Jagung bakar kini menjadi salah satu makanan tradisional yang cukup digemari oleh masyarakat. ${ }^{4}$

Makanan tradisional merupakan kelompok makanan yang diolah secara tradisional yang berkembang di masyarakat Indonesia. ${ }^{5}$ Makanan jajanan sebagian besar merupakan makanan yang diolah secara tradisional. ${ }^{6}$ Makanan jajanan jagung bakar belum sepenuhnya terjamin keamanan dari segi mikrobiologinya., Pencemaran mikroba pada makanan dapat melalui polusi lingkungan (debu, udara, tanah dan air), perilaku pengelolaan makanan, alat-alat pengolahan, ruang pengolahan dan bumbu penyedap. ${ }^{5,6,7}$

Kontaminasi yang terjadi pada makanan dapat menyebabkan makanan tersebut menjadi media bagi suatu penyakit. Penyakit yang ditimbulkan oleh makanan yang telah terkontaminasi disebut keracunan makanan. ${ }^{6,7}$ Keracunan makanan memiliki beberapa gejala dan tanda dari gangguan saluran cerna seperti diare, muntah-muntah, keram perut dan demam.,7-10 Sebagian besar kasus keracunan makanan diduga disebabkan oleh bakteri aerob, seperti Salmonella, Shigella, Escherichia coli, Vibrio cholera dan Staphylococcus aureus. ${ }^{5,8,11}$ Berdasarkan hasil penelitian yang dilakukan oleh Yolanda Arlita mengenai Escherichia coli dan Salmonella pada makanan jajanan bakso tusuk di Kota Manado, menunjukkan bahwa 17 (85\%) dari 20 sampel mengandung Escherichia coli dan 9 (45\%) dari 20 sampel mengandung Salmonella. ${ }^{12}$
Di Indonesia, diare merupakan salah satu penyakit endemik dengan angka morbiditas yang tinggi. ${ }^{10}$ Berdasarkan hasil survei morbiditas diare yang dilakukan oleh Kementerian Kesehatan tahun 19962010, angka kesakitan diare meningkat dari tahun 1996 sampai dengan 2006 yaitu tahun 1996 sebesar 280 per 1.000 penduduk, tahun 2000 sebesar 301 per 1.000 penduduk, tahun 2003 sebesar 374 per 1.000 penduduk, tahun 2006 sebesar 423 per 1.000 penduduk, kemudian menurun pada tahun 2010 yaitu 411 per 1.000 penduduk. ${ }^{10,13,14}$

Di Sulawesi Utara, berdasarkan data kasus keracunan makanan per provinsi oleh BPOM RI tahun 2007-2009, menunjukkan tahun 2007 sebesar 39 kasus, 2008 sebesar 9 dan 2009 sebesar 28 kasus. $^{5}$ Selain itu, berdasarkan data Riskesdas 2007, angka prevalensi diare adalah 5,4\% dan Riskesdas 2013, period prevalen diare adalah $6,6 \%{ }^{15,16}$

Berdasarkan fakta-fakta diatas, serta melihat kondisi lingkungan tempat penelitian, maka penulis tertarik untuk meneliti dari segi bakteriologis dengan mengidentifikasi bakteri aerob pada makanan jajanan jagung bakar di pinggiran jalan Ring Road Manado.

Tujuan dari penelitian ini yaitu untuk mengetahui bakteri aerob pada makanan jajanan jagung bakar di pinggiran jalan Ring Road Manado.

\section{METODE PENELITIAN}

Penelitian ini bersifat deskriptif prospektif yaitu untuk mengidentifikasi bakteri aerob pada makanan jajanan jagung bakar sebanyak 20 sampel, yang terdiri dari 10 jagung tidak dioleskan bumbu penyedap dan 10 jagung dioleskan bumbu penyedap di pinggiran jalan Ring Road Manado Periode Desember 2014 sampai dengan Januari 2015.

Sampel diambil secara acak (random sampling method). Pengambilan hapusan pada sampel jagung bakar dilakukan dengan cara usapan dengan lidi kapas steril yang telah diteteskan $\mathrm{NaCl}$ Fisiologis. 
Kemudian dilakukan penanaman pada media BGLB 2\%. Setelah itu dipindahkan ke media Nutrient Agar, Mac Conkey Agar dan SS Agar. Kemudian simpan dalam inkubator dengan suhu $37^{\circ} \mathrm{C}$ selama $24-48$ jam.Setelah terjadi pertumbuhan bakteri dengan membentuk koloni, maka selanjutnya dilakukan pewarnaan gram dan uji biokimia untuk mengidentifikasi bakteri.

\section{HASIL PENELITIAN}

Telah dilakukan penelitian bakteriologis pada 20 sampel makanan jajanan jagung bakar, yaitu 10 jagung bakar tidak dioleskan bumbu penyedap dan 10 jagung bakar dioleskan bumbu penyedap, yang diambil dengan teknik random sampling method dari 10 penjual di pinggiran jalan Ring Road Manado. Penelitian dilakukan di laboratorium Mikrobiologi FK UNSRAT dalam periode Desember 2014 - Januari 2015. Pengambilan sampel dapat diuraikan dalam tabel berikut. Jenis sampel ialah jagung bakar yang terdiri dari 10 sampel jagung bakar tidak dioleskan bumbu penyedap dan 10 sampel jagung dioleskan bumbu penyedap.

Tabel 1. Uraian Pengambilan Sampel

\begin{tabular}{ccc}
\hline $\begin{array}{c}\text { Jenis } \\
\text { Sampel }\end{array}$ & Kategori Sampel & $\begin{array}{c}\text { Jumlah } \\
\text { Sampel }\end{array}$ \\
\hline \multirow{2}{*}{$\begin{array}{c}\text { Jagung } \\
\text { Bakar }\end{array}$} & $\begin{array}{c}\text { Tidak Dioleskan } \\
\text { Bumbu Penyedap }\end{array}$ & 10 \\
\cline { 2 - 3 } & $\begin{array}{c}\text { Tidak Bumbu } \\
\text { Penyedap }\end{array}$ & 10 \\
\hline & Total & 20 \\
\hline
\end{tabular}

\section{Distribusi Sampel}

Distribusi sampel berdasarkan pertumbuhan bakteri pada media BGLB 2\%, Nutrient Agar, Mac Conkey Agar, dan Salmonella-Shigella Agar. Dari 20 sampel makanan jajanan jagung bakar yang diteliti, pertumbuhan bakteri terjadi pada BGLB 2\% sebanyak 18 sampel, Nutrient Agar sebanyak 18 sampel, Mac Conkey
Agar sebanyak 18 sampel, dan SalmonellaShigella Agar sebanyak 18 sampel. Dari 20 sampel, pertumbuhan bakteri terjadi pada BGLB 2\% sebanyak 18 sampel, Nutrient Agar sebanyak 18 sampel, Mac Conkey Agar sebanyak 18 sampel, dan SS Agar sebanyak 18 sampel.

Tabel 2. Distribusi Pertumbuhan Bakteri pada makanan jajanan Jagung Bakar

\begin{tabular}{ccccc}
\hline Media & BGLB & NA & MC & SS \\
Ada & 18 & 18 & 18 & 18 \\
$\begin{array}{c}\text { Pertumbuhan } \\
\text { Tidak Ada } \\
\text { Pertumbuhan }\end{array}$ & 2 & 2 & 2 & 2 \\
\hline Total & 20 & 20 & 20 & 20 \\
\hline
\end{tabular}

\section{Hasil Pewarnaan Gram}

Penelitian ini dilakukan di Laboratorium Mikrobiologi Fakultas Kedokteran Universitas Sam Ratulangi Manado terhadap 18 sampel makanan jajanan jagung bakar, dimana 9 sampel jagung bakar tidak dioleskan bumbu penyedap ditemukan 1 sampel bakteri gram positif, 2 sampel bakteri gram negatif, dan 6 sampel bakteri gram positif dan negatif, kemudian 9 sampel jagung bakar dioleskan bumbu penyedap ditemukan 1 sampel bakteri gram positif, 3 sampel bakteri gram negatif, dan 5 sampel bakteri gram positif dan negatif. Hal ini dapat diuraikan dalam tabel berikut.

Tabel 3. Hasil Pewarnaan Gram pada Jagung Bakar Tidak Dioleskan Bumbu Penyedap

\begin{tabular}{ccc}
\hline Gram & $\begin{array}{c}\text { Jumlah } \\
\text { Sampel }\end{array}$ & $\begin{array}{c}\text { Persentase } \\
(\%)\end{array}$ \\
\hline Gram Positif & 1 & 11,11 \\
Gram Negatif & 2 & 22,22 \\
Gram Positif & 6 & 66,67 \\
dan Negatif & 9 & 100 \\
Total & 9 \\
\hline
\end{tabular}

Tabel 3 menunjukkan bakteri Gram positif 1 sampel (11,11\%), bakteri Gram negatif 2 sampel (22,22\%) dan bakteri Gram positif dan negatif yaitu 6 sampel 
$(66,67 \%)$.

Tabel 4. Hasil Pewarnaan Gram pada Jagung Bakar Dioleskan Bumbu Penyedap

\begin{tabular}{ccc}
\hline Gram & $\begin{array}{c}\text { Jumlah } \\
\text { Sampel }\end{array}$ & $\begin{array}{c}\text { Persentase } \\
(\%)\end{array}$ \\
\hline Gram Positif & 1 & 11,11 \\
Gram Negatif & 3 & 33,33 \\
Gram Positif & 5 & 55,56 \\
dan Negatif & 9 & 100 \\
Total & & \\
\hline
\end{tabular}

Tabel 4 menunjukkan bakteri Gram positif 1 sampel (11,11\%), bakteri Gram negatif 3 sampel $(33,33 \%)$ dan bakteri Gram positif dan negatif yaitu 5 sampel $(55,56 \%)$.

\section{Distribusi Pertumbuhan Bakteri}

Pemeriksaan makanan jajanan jagung bakar dilakukan di Laboratorium Mikrobiologi Fakultas Kedokteran UNSRAT Manado terdapat 18 sampel. Tabel 5 menunjukkan hasil biakan bakteri pada 9 jagung bakar tidak dioleskan bumbu penyedap dimana bakteri Bacillus subtilis sebesar 5 sampel (31,25\%), Enterobacter agglomerans sebesar 4 sampel (25\%), Serratia rubidaea sebesar 2 sampel (12,5\%), Lactobacillus sp. sebesar 2 sampel (12,5\%), Kokus gram negatif sebesar 2 sampel (12,5\%), dan Enterobacter cloacae sebesar 1 sampel $(6,25 \%)$.

Tabel 5. Hasil Identifikasi Bakteri pada Jagung Bakar Tidak Dioleskan Bumbu Penyedap

\begin{tabular}{ccc}
\hline Bakteri & Jumlah & $\begin{array}{c}\text { Persentase } \\
(\%)\end{array}$ \\
\hline Bacillus subtilis & 5 & 31,25 \\
Enterobacter & 4 & 25 \\
agglomerans & & \\
Serratia rubidaea & 2 & 12,5 \\
Lactobacillus sp. & 2 & 12,5 \\
Kokus Gram negatif & 2 & 12,5 \\
Enterobacter cloacae & 1 & 6,25 \\
Total & 16 & 100 \\
\hline
\end{tabular}

Tabel 6 menunjukkan hasil biakan bakteri pada 9 jagung bakar dioleskan bumbu penyedap dimana bakteri Bacillus subtilis sebesar 6 sampel (37,5\%), Enterobacter agglomerans sebesar 3 sampel (18,75\%), Serratia rubidaea sebesar 2 sampel (12,5\%), Lactobacillus sp. sebesar 2 sampel (12,5\%), Enterobacter cloacae sebesar 1 sampel (6,25\%), Streptococcus sp. sebesar 1 sampel (6,25\%), dan Pseudomonas sp. sebesar 1 sampel $(6,25 \%)$.

Tabel 6. Hasil Identifikasi Bakteri pada Jagung Bakar Dioleskan Bumbu Penyedap

\begin{tabular}{ccc}
\hline Bakteri & Jumlah & Persentase (\%) \\
\hline Bacillus subtilis & 6 & 37,5 \\
Enterobacter & 3 & 18,75 \\
agglomerans & & \\
Serratia rubidaea & 2 & 12,5 \\
Lactobacillus sp. & 2 & 12,5 \\
$\quad$ Enterobacter & 1 & 6,25 \\
$\quad$ cloacae & & \\
Streptococcus sp. & 1 & 6,25 \\
Pseudomonas sp. & 1 & 6,25 \\
$\quad$ Total & 16 & 100 \\
\hline
\end{tabular}

\section{BAHASAN}

Dalam periode Desember 2014 Januari 2015, telah diteliti 20 sampel berupa makanan jajanan jagung bakar, yaitu 10 jagung bakar tidak dioleskan bumbu penyedap dan 10 jagung bakar dioleskan bumbu penyedap di pinggiran jalan Ring Road Manado. Pengambilan sampel dilakukan dengan teknik random sampling method dan dibeli 2 makanan jajanan jagung bakar, masing-masing 1 jagung bakar tidak dioleskan bumbu penyedap dan 1 jagung bakar dioleskan bumbu penyedap dari 1 penjual. Pemeriksaan dilakukan di Laboratorium Mikrobiologi Fakultas Kedokteran Universitas Sam Ratulangi. Pemeriksaan Mikrobiologi yang dilakukan pada sampel adalah penanaman pada media pertumbuhan, pewarnaan gram, dan uji biokimia.

Pada penelitian dari 20 sampel yang diperiksa, terdapat 18 sampel terdapat 
pertumbuhan dan 2 sampel tidak terdapat pertumbuhan. Hasil pemeriksaan Bakteriologis, yaitu terdapat pembentukan koloni pada media pertumbuhan, selanjutnya mengidentifikasi secara mikroskopis dari hasil pewarnaan gram, dan mengidentifikasi melalui uji biokimia, maka 9 sampel jagung bakar tidak dioleskan bumbu penyedap ditemukan 6 jenis bakteri yaitu Bacillus subtilis, Enterobacter agglomerans, Serratia rubidaea, Lactobacillus sp., Kokus gram negatif, dan Enterobacter cloacae dan 9 sampel jagung bakar dioleskan bumbu penyedap ditemukan 7 jenis bakteri yaitu Bacillus subtilis, Enterobacter agglomerans, Serratia rubidaea, Lactobacillus sp., Enterobacter cloacae, Streptococcus sp., dan Pseudomonas sp.

Bacillus subtilis merupakan bakteri yang dapat membentuk endospora bersifat protektif untuk menahan suhu ekstrim dan lingkungan kering. Bacillus subtilis biasanya ditemukan di udara, air, dan tanah. Bacillus subtilis sangat berhubungan dengan food poisoning (foodborne illness). Bacillus subtilis menyebabkan gejala nyeri abdominal, mual, muntah dan diarrhoea. Berdasarkan penelitian oleh ApetroaieConstantin C., dkk mengenai Bacillus subtilis and $B$. mojavensis strains connected to food poisoning produce the heat stable toxin amylosin, Bacillus subtilis terisolasi pada 1 dari 10 sampel makanan dengan jenis yang berbeda. Oleh karena tempat penelitian saya ini terdapat di Ring Road Manado, sangat memungkinkan terjadinya kontaminasi pada makanan jajanan ini akibat polusi udara. ${ }^{17-19}$

Enterobacter agglomerans atau dikenal dengan Pantoea agglomerans adalah bakteri golongan famili Enterobacteriaceae biasanya ditemukan dan terisolasi di bahan makanan, sayuran, dan biji-bijian. Enterobacter agglomerans dapat menyebabkan diare, mual, dan muntah. Berdasarkan penelitian yang dilakukan oleh Shaker R., dkk mengenai isolation of Enterobacter sakazakii and Enterobacter sp. from food and food production environments, Enterobacter agglomerans terisolasi pada 1 dari 3 sampel (33,3\%) produk makanan sereal, 2 dari 10 sampel (20\%) produk susu bubuk bayi, 2 dari 15 sampel (13,33\%) produk makanan bayi, dan 2 dari 8 sampel (25\%) produk susu bayi. Hasil penelitian di atas sama dengan penelitian yang saya lakukan, yaitu ditemukannya bakteri Enterobacter agglomerans. Hal ini menandakan bahwa pengolahan jagung bakar di pinggiran jalan Ring Road Manado tidak higienis. ${ }^{20-22}$

Serratia rubidaea merupakan bakteri golongan famili Enterobacteriaceae yang dapat terisolasi pada makanan, seperti sayuran, tomat dan salad. Jika mengonsumsi makanan yang terkontaminasi Serratia rubidaea, secara patogen akan menyebakan infeksi saluran pencernaan. Berdasarkan penelitian yang dilakukan oleh Hemida M., dkk mengenai isolation and characterization of Serratia rubidaea from dark brown spots of tomato fruits, ditemukan 38 sampel mengandung Serratia rubidaea. Ada pula penelitian oleh Falomir M., dkk mengenai Coliform bacteria in fresh vegetables: from cultivated lands to consumers, ditemukan 1 dari 10 sampel tomat mengandung Serratia rubidaea. Hasil penelitian di atas sama dengan penelitian yang saya lakukan, yaitu ditemukannya bakteri Serratia rubidaea. Hal ini menandakan bahwa pengolahan jagung bakar di pinggiran jalan Ring Road Manado tidak higienis. ${ }^{23-25}$

Enterobacter cloacae merupakan bakteri golongan famili Enterobacteriaceae yang hidup di lingkungan mesofilik dengan suhu optimal $37^{\circ} \mathrm{C}$. Enterobacter cloacae biasanya ditemukan pada buah-buahan dan sayuran. Enterobacter cloacae merupakan bakteri patogen yang menyebabkan infeksi intra abdominal, nausea, vomiting, dan diare. Berdasarkan penelitian yang dilakukan oleh Haryani Y., dkk mengenai Characterization of Enterobacter cloace isolated from Street Food, Enterobacter cloacae terisolasi pada 1 dari 3 sampel Kuah Chutney di Kota Seremban, 2 dari 3 
sampel Tauhu Sumbat di Kota Kuala Pilah, dan 1 dari 1 sampel Surimi Lobster di Kota Kuala Pilah. Hasil penelitian di atas sama dengan penelitian yang saya lakukan, yaitu ditemukannya bakteri Serratia rubidaea. Hal ini menandakan bahwa pengolahan jagung bakar di pinggiran jalan Ring Road Manado tidak higienis. ${ }^{21,26,27}$

Pseudomonas sp. merupakan bakteri yang hidup aerob yang ditemukan pada makanan, air, dan tanah. Pseudomonas sp. menyebabkan gejala diare dan peradangan. Berdasarkan penelitian oleh Tabashsum Z., dkk mengenai Prevalence of Foodborne Pathogens and Spoilage Microorganisms and Their Drugs Resistant Status in Different Street Foods of Dhaka City, Pseudomonas sp. terisolasi pada 1 dari 3 sampel pitha, 1 dari 3 sampel jilapi, 2 dari 3 sampel cucumber, dan 3 dari 3 sampel air. Hasil penelitian tersebut di atas sama dengan hasil penelitian saya, yaitu ditemukannya Pseudomonas sp. pada jagung bakar dioleskan bumbu penyedap. $^{28,29}$

Lactobacillus sp. adalah bakteri non patogen dan jenis bakteri menguntungkan yang disebut probiotik. Lactobacillus sp. normalnya ditemukan pada usus dan vagina, serta pada produk susu berfermentasi, seperti yogurt. Berdasarkan penelitian oleh Tabashsum Z., dkk mengenai Prevalence of Foodborne Pathogens and Spoilage Microorganisms and Their Drugs Resistant Status in Different Street Foods of Dhaka City, Lactobacillus sp. terisolasi pada 3 dari 3 sampel singara, 3 dari 3 sampel muri, 3 dari 3 sampel chatpati. Berdasarkan hasil penelitian tersebut di atas, didapatkan Lactobacillus sp. akibat terkontaminasi pada proses pengolahan dari tangan pengelola yang sebelumnya bersentuhan dengan sumber bakteri. ${ }^{29,30}$

Streptococcus sp. dapat menyebabkan foodborne disease akibat terkontaminasi dari droplet pengelola yang kemungkinan menderita infeksi saluran pernapasan. Foodborne disease akibat Streptococcus sp menunjukkan beberapa gejala, seperti diare, nyeri perut, mual dan muntah. ${ }^{31}$

Kokus gram negatif pada penelitian makanan jajanan jagung bakar di pinggiran jalan Ring Road Manado tidak teridentifikasi jenis bakteri secara spesifik.

\section{SIMPULAN}

Berdasarkan hasil penelitian identifikasi bakteri aerob pada makanan jajanan jagung bakar di pinggiran jalan Ring Road Manado, maka dapat disimpulkan bahwa jumlah bakteri yang ditemukan dari 20 sampel makanan jajanan jagung bakar, ditemukan 18 sampel terjadi pertumbuhan dan 2 sampel tidak terjadi pertumbuhan. Dari 18 sampel makanan jajanan jagung bakar, ditemukan 6 jenis bakteri pada 9 sampel jagung bakar tidak dioleskan bumbu penyedap, yaitu Bacillus subtilis, Enterobacter agglomerans, Serratia rubidaea, Lactobacillus sp., Kokus gram negatif, dan Enterobacter cloacae dan 7 jenis bakteri pada 9 sampel jagung bakar dioleskan bumbu penyedap, yaitu Bacillus subtilis, Enterobacter agglomerans, Serratia rubidaea, Lactobacillus sp., Enterobacter cloacae, Streptococcus sp., dan Pseudomonas sp. Hal ini menandakan bahwa pengolahannya tidak higienis

\section{DAFTAR PUSTAKA}

1. Cyber Extension Kementerian Pertanian, Badan Penyuluhan dan Pengembangan Sumber Daya Manusia Pertanian. Jagung Sebagai Bahan Pangan, Pakan Ternak dan Bahan Baku Industri. 2005 [cited 2014 Oct 11]. Available from: http://cybex.deptan.go.id/penyuluhan/j agung-sebagai-bahan-pangan-pakanternak-dan-bahan-baku-industri

2. Tanindo Agribusiness Company, PT. Tanindo Intertraco. Memanfaatkan Jagung Sebagai Sumber Pangan Alternatif. 2014 [cited 2014 Oct 11]. Available from: http://www.tanindo.com/index.php?opt ion $=$ com_content\&view $=$ article\&id=5 39:memanfaatkan-jagung-sebagaisumber-panganalternatif\&catid=559:memanfaatkanjagung-sebagai-sumber-panganalternat\&Itemid=149 
3. Badan Pengembangan, Pelatihan dan Promosi Ekspor Daerah (BP3ED), Dinas Perindustrian dan Perdagangan Provinsi NTB. Pengolahan Pangan Jagung. 2012 [cited 2014 Oct 11]. Available from: http://bp3ed.disperindag.ntbprov.go.id/ index.php/profil/19-fungsional/39pengolahan-pangan-jagung

4. Tanijogonegoro, Peluang Usaha Bisnis Makanan dari Jagung. 2013 [cited 2014 Oct 11]. Available from: http://www.tanijogonegoro.com/2013/0 9/PELUANG-USAHA-BISNISMAKANAN.html

5. Handayani BR, Werdiningsih W. Kondisi Sanitasi dan Keracunan Makanan Tradisional. 2010 Dec [cited 2014 Sep 14]. Available from: http://fp.unram.ac.id/data/2012/04/202-3_07-Rien-Kondisi-sanitasikeracunan-mkn-trad_Rev-Eko_P.pdf

6. Agustina F, Pambayun R, Febry F. Higiene dan Sanitasi pada Pedagang Makanan Jajanan Tradisional di Lingkungan Sekolah Dasar di Kelurahan Demang Lebar Daun Palembang Tahun 2009. 2009 [cited 2014 Sep 13]. Available from: eprints.unsri.ac.id/64/3/Abstrak8.pdf

7. Badan POM RI. Pengujian Mikrobiologi Makanan. InfoPOM Pengawas Obat dan Makanan Republik Indonesia Vol. 9, No. 2. Maret 2008. [cited 2014 Sep 13].

Available from:http://perpustakaan.pom.go.id/Ko leksiLainnya/Buletin\%20Info\%20POM /0208.pdf

8. Irianto K. Mikrobiologi Medis: Pencegahan, Pangan, Lingkungan. Bandung: Alfabeta; 2013.

9. WHO. Penyakit Bawaan Makanan: Fokus Pendidikan Kesehatan. Widyastuti P, editor. Jakarta: EGC; 2006.

10. Korompis F, Tjitrosantoso H, Goenawi LR. Studi Penggunaan Obat pada Diare Akut di Instalasi Rawat Inap BLU RSUP PROF. R. D. Kandou Manado Periode Januari-Juni 2012. Jurnal Ilmiah Farmasi - UNSRAT. 2013.2;42-3

11. Chatim A, Sjahrurachman A, Soebandrio WK, Kurniawati A, Santoso AU, Harun BM, et al. Penuntun Praktikum
Mikrobiologi Kedokteran. Jakarta: Binapura Aksara; 1991.

12. Arlita Y, Rares F, Soeliongan S. Identifikasi Bakteri Escherichia coli dan Salmonella sp. pada Makanan Jajanan Bakso Tusuk di Kota Manado. 2014 [cited 2014 Sep 9]. Available from:

http://download.portalgaruda.org/articl e.php?article $=157332 \&$ val $=1008 \&$ title =IDENTIFIKASI\%20BAKTERI\%20E SCHERICHIA\%20COLI\%20DAN\%2 OSALMONELLA\%20SP.\%20PADA\% 20MAKANAN\%20JAJANAN\%20BA KSO\%20TUSUK\%20DI\%20KOTA\% 20MANADO

13. Kementrian Kesehatan RI. Buletin Jendela Data dan Informasi Kesehatan. Situasi Diare di Indonesia. 2011 [cited 2014 Sep 1]. Available from: http://www.depkes.go.id/download.php ?file=download/pusdatin/buletin/buleti n-diare.pdf

14. Motto SY, Masloman N, Manoppo JC. Tingkat Pengetahuan Ibu tentang Diare pada Anak di Puskesmas Bahu Manado. Jurnal e-Biomedik (eBM). 2013;1:807.

15. Riskesdas 2007. Jakarta: Badan Penelitian dan Pengembangan Kesehatan Depkes RI; 2008.

16. Riskesdas 2013. Jakarta: Badan Penelitian dan Pengembangan Kesehatan Depkes RI; 2013.

17. Ariyadi T, Sinto S. Pengaruh Sinar Ultraviolet Terhadap Pertumbuhan Bakteri Bacillus sp. sebagai Bakteri Kontaminan. Jurnal Kesehatan Universitas Muhammadiyah Semarang. 2009 Dec [cited 2015 Jan 20]. Available from: http://download.portalgaruda.org/articl e.php?article $=4777 \& \mathrm{val}=433$

18. Apetroaie-Constantin C. Bacillus subtilis and B. Mojavensis Strains Connected to Food Poisoning Produce the Heat Stable Toxin Amylosin. Journal of Applied Microbiology. 2009 [cited 2015 Jan 20]. Available from: http://www.researchgate.net/profile/Ma ria_Andersson2/publication/24026159_ Bacillus_subtilis_and_B._mojavensis_ strains_connected_to_food_poisoning produce_the_heat_stble_toxin_amylosi 
n/links/542e800f0cf29bbc126f265d.pd $\mathrm{f}$

19. Cambridge City Council. Bacillus Food Poisoning. [cited 2015 Jan 20]. Available from: https://www.cambridge.gov.uk/sites/w ww.cambridge.gov.uk/files/docs/Bacill us\%20food\%20poisoning.pdf

20. Wikipedia The Free Encyclopedia. Pantoea agglomerans. [cited 2015 Jan 20]. Availaable from: http://en.wikipedia.org/wiki/Pantoea_a gglomerans

21. Chen H. Determination of Histamine and Histamine-forming Bacteria in Tuna Dumpling Implicated in a Foodborne Poisoning. Science Direct. 2007 [cited 2015 Jan 20]. Available from: http://www.researchgate.net/publicatio n/222826950_Determination_of_hista mine_and_histamine-

forming_bacteria_in_tuna_dumpling_i mplicated_in_a_food-

borne_poisoning/links/0fcfd508f7dca0 567f000000.pdf

22. Shaker R. Isolation of Enterobacter sakazakii and Other Enterobacter sp. From Food and Food production Environments. Science Direct. 2006 [cited 2015 Jan 20]. Available from: http://www.researchgate.net/publicatio n/222561420_Isolation_of_Enterobacte r_sakazakii_and_other_Enterobacter_s p._from_food_and_food_production_e nvironments/links/0912f50d1e50a9886 6000000.pdf

23. ABIS Encyclopedia. Genus Serratia. [cited 2015 Jan 20]. Available from: http://www.tgw1916.net/Enterobacteria /Serratia.html

24. Falomir M, Gozalbo D. Coliform Bacteria in Fresh Vegetables: From Cultivated Lands to Consumer. Technology and Education Topics in Applied Microbiology and Microbal Biotechnology. 2010 [cited 2015 Jan 20]. Available from: http://www.formatex.info/microbiolog y2/1175-1181.pdf

25. Hemida M, Bashandy S. Isolation and Characterization of Serratia rubidaea from Dark Brown Spots of Tomato Fruits. Spinger: Science and Business Media. 2011 Mar [cited 2015 Jan 20].
Available

from: http://www.researchgate.net/profile/Mo hamed_Abd-

Alla3/publication/225656905_Isolation _and_characterization_of_Serratia_rubi daea_from_dark_brown_spots_of_tom ato_fruits/links/53fc6fae0cf22f21c2f3d 7e9.pdf

26. Microbewiki. Enterobacter cloacae. 2013 Aug [cited 2015 Jan 20]. Available from:

https://microbewiki.kenyon.edu/index. php/Enterobacter_cloacae

27. Haryani Y, Tunung R, Chai L. Characterization of Enterobacter cloacae Isolated from Street Foods. ASEAN Food Journal. 2008 [cited 2015 Jan 20]. Available from: http://www.ifrj.upm.edu.my/afjv15\%2 81\%292008/57-64.pdf

28. Franzetti L, Scarpellini M. Characterization of Pesudomonas spp. Isolated from foods. Annals of Microbiology. 2007 [cited 2015 Jan 20]. Available from: http://www.researchgate.net/profile/La ura_Franzetti/publication/226159158_ Characterisation_ofPseudomonas_spp. _isolated_from_foods/links/0c96052bb 1661f24ca000000.pdf

29. Tabashsum Z, Khalil I. Prevalence of Foodborne Pathogens and Spoilage Microorganisms and Their Drug Resistent Status in Different Street Foods of Dhaka City. Agriculture Food and Analytical Bacteriology. 2013 [cited 2015 Jan 20]. Available from: http://afabjournal.com/wpcontent/uploads/AFAB_v3_i4_pp281292.pdf

30. Go Ask Alice. Lactobacillus acidophilus. Columbia Health. [cited 2015 Jan 20]. Available from: http://goaskalice.columbia.edu/lactobac illus-acidophilus-diarrhea

31. Kaluski D, Barak E. A Large Foodborne Outbreak of Group A Streptococcal Pharyngitis in an Industrial Plant: Potential for Deliberate Contamination. IMAJ. 2008 [cited 2015 Jan 20]. Available from: https://www.ima.org.il/FilesUpload/IM AJ/0/49/24664.pdf 